\title{
Morphological and Syntactic Aspects of Indefinite Pronouns in Iliatenco Me'phaa
}

Philip T. Duncan (University of Kansas)

1. Introduction In this paper I discuss indefinite pronouns (e.g., 'somebody', 'something') in Iliatenco Me'phaa., ${ }^{1,2}$

(1) $\boldsymbol{m b a ́} \quad$ tsi $\quad n i$ '-t-á $\boldsymbol{m b a ́}$

AFF.INDF REL COMPL.AFF-write-3SG.AN AFF.INDF

'Someone wrote something'

Me'phaa is of typological interest because it possesses a rare type of indefinite system, based on the numeral 'one' (Haspelmath 1997:29). After attending to background, I present the morphological system and some syntactic properties of indefinite pronouns in the language. I show that while indefinite pronouns in Iliatenco Me'phaa are unique typologically, the overall paradigm still preserves a feature that is common crosslinguistically: the encoding of a person $v s$. non-person distinction through the use of numeral based and whbased indefinites.

2. Background Me'phaa (also known as "Tlapanec") is a member of the Otomanguean language family and consists of about eight distinct varieties spoken by approximately 100,000 people in eastern Guerrero, Mexico (INEGI 2005). ${ }^{3}$ In addition to this, some Me'phaa speakers reside in the U.S. Since June 2010, I have been working with Me'phaa consultants in the U.S. who are from the Iliatenco municipality of Guerrero. ${ }^{4}$

The Me'phaa language is severly underdocumented. There is one detailed description of the morphophonology of the Malinaltepec variety (Carrasco Zúñiga 2006) and a few descriptive papers of varying lengths (e.g., Suárez 1988; Weathers 1976, among others). Currently, there is a more extensive project underway aimed at documenting all varieties of the Me'phaa genus (Marlett 2011). To my knowledge, however, there is no literature that focuses specifically on indefinite pronouns in Me'phaa of any variety.

Iliatenco Me'phaa exhibits canonical VSO word order in simple declarative sentences (2a), though other orderings are possible $(2 b-c)$ :

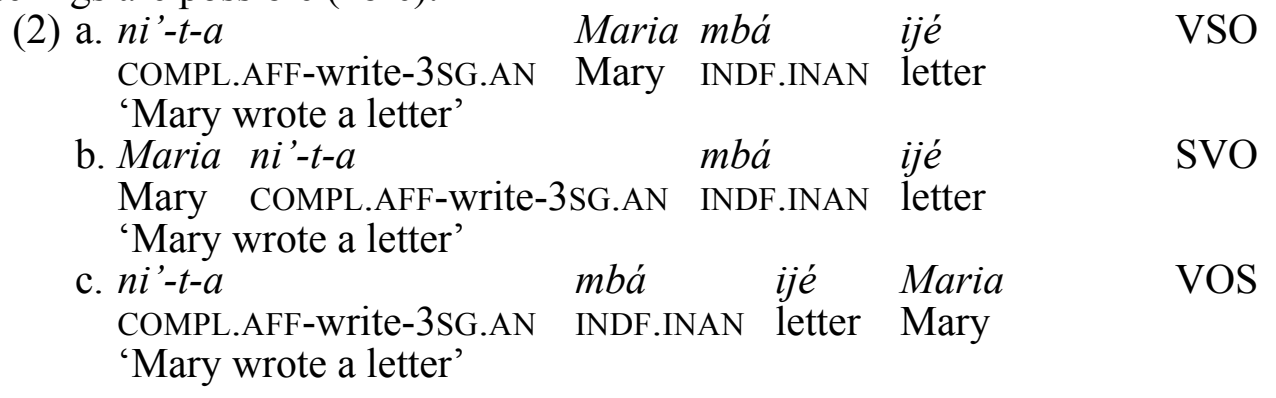

3. Typology of Indefinite Pronouns Haspelmath (1997) presents a typological survey of indefinite pronoun systems. Morphologically, he identifies three kinds of systems. "Ontological category-based" indefinites delineate a series that is structured around a set of basic ontological category nouns (e.g., "person," "place," "thing," etc.). Second, "interrogative-based" indefinite pronouns are those that are either homophonous with or built from wh-expressions. This type is the most common cross-linguistically. Finally, the least common type of

\footnotetext{
${ }^{1}$ Ethnologue lists the variety spoken in the Iliatenco municipality as Malinaltepec Me'phaa (Lewis 2009).

${ }^{2}$ Following the 2008 Leipzig glossing rules, common abbreviations used are: $1=$ first person, $2=$ second person, $3=$ third person, $\mathrm{COMP}=$ complementizer, $\mathrm{COMPL}=$ completive, $\mathrm{INDF}=$ indefinite, $\mathrm{IRR}=$ irrealis, $\mathrm{NEG}=$ negative, $\mathrm{Q}=$ question/intterogative particle, $\mathrm{REL}=$ relative, $\mathrm{SG}=$ singular. Additional abbreviations are: $\mathrm{AFF}=$ affirmative, $\mathrm{AN}=$ animate, $\mathrm{EXIST}=$ existential, $\mathrm{INAN}=\mathrm{inanimate}$, $\mathrm{INC}=$ incompletive, $\mathrm{V}=$ high tone, $\mathrm{V}=$ mid tone, $\underline{\mathrm{V}}=$ low tone.

${ }^{3}$ The name for the language in the variety represented here is Ajngáa Méphaa 'the Me'phaa language' (Lit., 'word Me'phaa').

"Tlapanec" was given by Náhuatl speakers and is dispreferred by some Me'phaa speakers.

${ }^{4}$ Many thanks to the Me'phaa consultants for collaborating with me for this and other projects: Jacinta Simón, Eduardo Luna, Félix Castañeda, Rubén Castañeda, and Raúl Castañeda. Without them, this work would not be possible, and I am grateful to each of them for sharing their language. Thanks also to Abad Carrasco Zúñiga and Stephen Marlett for their help. Also, thanks to Professor Harold Torrence for his assistance with the data presented here, and to my wife Monica for her encouragement.
} 
indefinite pronoun series is "“one'-based," which is built from the numeral 'one.' Examples from English can serve to illustrate each type:
(3) a.some-body
Ontological category
b.some-thing
Interrogative
Numeral 'one'
c. some-where
e. some-one
d. some-how

In cases like (3e) where 'one'-based indefinites are used, they commonly pattern as exceptions that correspond to the ontological category "person" (Haspelmath 1997:183-184). However, Iliatenco Me'phaa exhibits the opposite pattern for indefinite pronouns, wherein: (a) 'one'-based indefinites are more typical, while (b) the person category is derived differently (interrogative-based).

4. Indefinite Pronouns in Iliatenco Me'phaa Bare nouns are often ambiguous with regard to specificity (4a). If $m b a$ ' 'one' is added then the noun is interpreted as indefinite (4b).
(4) a. Pedro ni-guxxn-o
ijé
Peter COMPL.AFF-read-3SG.AN book
b. Pedro ni-guxn-o
$m b a ́$
Peter COMPL.AFF-read-3SG.AN INDF-INAN
ijé
'Peter read (a/the) book'
'Peter read a book'

That the numeral 'one' is the base for the indefinite article is not surprising given that indefinite articles are frequently grammaticalized forms of the numeral 'one' cross-linguistically (Haspelmath 1997:29; Givón 1981). ${ }^{5}$ Similarly, as Table 1 shows, 'one' is the primary base for indefinite pronouns in Iliatenco Me'phaa.

TABLE 1. Interrogative and indefinite pronouns in Iliatenco Me'phaa.

\begin{tabular}{|c|c|c|c|c|c|}
\hline \multirow[t]{2}{*}{$\begin{array}{l}\text { Ontological } \\
\text { Category }\end{array}$} & \multirow[t]{2}{*}{$\begin{array}{l}\text { Interrogative } \\
\text { pronoun }\end{array}$} & \multicolumn{4}{|c|}{$\begin{array}{l}\text { Indefinite } \\
\text { pronoun }\end{array}$} \\
\hline & & \multicolumn{2}{|c|}{ interrogative-based } & \multicolumn{2}{|c|}{ 'one'-based } \\
\hline person & tsá & tsá, mbá tsi & $t s u ́ \sim t s i$ & mbá tsi & nimbá \\
\hline & 'who?' & 'someone' & 'no one' & 'someone' & 'no one' \\
\hline thing & di(ne) & & & $m b a ́$ & nimbá \\
\hline & 'what?' & & & 'something' & 'nothing' \\
\hline place & náá & & & $m b a ́$ & nimbá \\
\hline & 'where?' & & & 'somewhere' & 'nowhere' \\
\hline time & $\begin{array}{l}(g w a) n a, \text { nóra } \\
\text { 'when?' }\end{array}$ & & & $\begin{array}{l}\text { mbá xugi } \\
\text { 'always' }\end{array}$ & $\begin{array}{l}\text { nimbá mi'tsú } \\
\text { 'never' }\end{array}$ \\
\hline manner & $\begin{array}{l}\text { xáni } \\
\text { 'how?' }\end{array}$ & & & & \\
\hline amount & $\begin{array}{l}t i, \text { gwa tha } \\
\text { 'how many?' }\end{array}$ & & & & \\
\hline
\end{tabular}

The lexical items in this table illustrate that, with exceptions from the ontological category "person," there is no correlation between $w$ h-elements and indefinite pronouns. Instead, as with the indefinite article, the numeral $m b a ́$ ' one' is the derivational base for the indefinite pronouns meaning 'something' (5) and 'somewhere':
(5) Pedro ni-guxn-o
mbá
Pedro COMPL.AFF-read-3SG.AN AFF.INDF
'Peter read something'

Non-person subject numeral indefinites occur with the existential rigá and a relative clause (6a). However, without the existential, the sentence is ungrammatical, suggesting a subject-object asymmetry for non-person indefinites that is common cross-linguistically (Haspelmath 1997:214-218): ${ }^{6}$

\footnotetext{
${ }^{5}$ I consider the numeral 'one' to have multiple phonological forms. Suárez (1983:636) and Carrasco Zúñiga (2006:15, 167) list $m b a ́$ as the form for the cardinal numeral 'one', though, as Marlett (2011:6) notes, this may be an error since speakers consistently use $m b o ́ o ́$ when responding 'one' to questions such as "How many tortillas are there on the table?" However, some speakers do supply mbá for 'one' when counting, and this may be an effect of bilingualism or phonological similarity with higher numerals where $m b a ́$ functions as an operand (e.g., as a multiplicand, as in mbá skijún 'twenty' $(1$ x $20=20))$.

${ }^{6}$ This tendency is, however, more common typologically among SVO languages and in the context of negation (e.g., 'I didn't see anybody' vs. '*Anybody didn't come' [Haspelmath 1997:214]).
} 
(6) a. rígá mbá ri ni-xn-u Maria

EXIST AFF.INDF COMP COMPL-hit-3SG.AN Mary

'Something hit Mary' (Lit., 'There is something that hit Mary')

b. *mbá Mi-xn-u Maria

AFF.INDF COMPL.AFF-hit-3SG.AN Mary

(Intended: 'Something hit Mary')

5. Negative Indefinites Haspelmath (1997:193-200) outlines four principal syntactic means of expressing negated indefinites. Iliatenco Me'phaa utilizes the following two types for negating indefinites: (a) verbal negation plus (ordinary) indefinite, and (b) verbal negation plus 'negative indefinite.' In Iliatenco Me'phaa, a greater amount of neutralization occurs in the negative category of Me'phaa indefinites, collapsing the ontological categories "person", "thing", and "place" (see Table 1).

'One'-based negative indefinites in Iliatenco Me'phaa are morphologically complex, and are formed by adding the prefix $n i$ - to the numeral base. Moreover, they co-occur with verbal negation obligatorily.

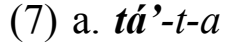
Maria (ni-)mbá
COMPL.NEG-write -3SG.AN Mary (NEG-)INDF
'Mary didn't write anything'
b. * $\boldsymbol{n i}-t-a$
Maria ni-mbá
INC.AFF-write -3SG.AN Mary NEG-INDF
(Intended: 'Mary wrote nothing')

Negative indefinites do not, however, require local negation. They can be licensed by non-clausemate negation:

(8) a. na-honm-o' ri ikhaa ta-guxn-o' ni-mbá

INC.AFF-think-1SG COMP 3SG COMPL.NEG-read-3SG.AN NEG-INDF

'I think that he didn't read anything'

b. 'tsi-nemb-o ri ikhaa ni-guxn-o ni-mbá

INC.NEG-doubt-1SG COMP 3SG COMPL.AFF-read-3SG.AN NEG-INDF

'I don't think that he read anything'

Like ordinary DPs, Iliatenco Me'phaa allows varying word order for sentences with indefinite pronouns.

(9)
a. $n i$ '- - - $a$
Maria
mbá
VSO
COMPL.AFF-write-3SG.AN,
'Mary wrote something'
b. mbá Maria ni'ta
AFF.INDF
'Mary wrote something'
c. Maria ni'ta mbá
'Mary wrote something
OSV
SVO

(10)
a. Maria ta'-xum-a
Mary COMPL.NEG-send-3SG.AN INDF letter
'Mary didn't send a letter to anyone'
b. Maria ta'xuma nimbá mbá letra
'Mary didn't send a letter to anyone'
SV DO IO
SV IO DO

However, some indefinites have a more restricted distribution than ordinary DPs, for example, mbá cannot appear as a sentence-initial subject without an existential (6a-b).

6. Interrogative-Based Indefinites Indefinite pronoun forms belonging to the category "person" are interrogative-based. The "person" category appears to be the only one in Iliatenco Me'phaa that includes interrogative-based simple indefinite pronouns. Wh-movement is obligatory; wh-elements are illicit in situ:
(11)
who COMPL.AFF-hit-3SG.AN John
'Who hit John?'
a. tsá Juan
b. *ni-xn-u tsá Juan
COMPL.AFF-hit-3SG.AN who John
(Intended: 'Who hit John?')

The $w h$-question and indefinite expression are ambiguous when $t$ sá 'who?/someone' is used sentence-initially. Accordingly, (11a) may also mean 'someone hit John' ([11b], however, is out under this reading, as well).

Like regular DPs, the interrogative-based indefinite $t s a$ ' 'someone' and the negative indefinite nimbá 'no one' appear sentence-finally as object indefinites:
(12) Maria ni-xn-u
Mary COMPL.AFF-hit-3SG who
'Mary hit someone' 

(13)
nanguá
tha- $y-O$
nimbá
no COMPL.NEG-See-1SG
NEG.INDEF
'No, I did not see anyone'

The affirmative, interrogative-based tsá and mbá tsi pattern differently in terms of syntactic position. Unlike tsá, the interrogative indefinite $m b a ́$ tsi 'someone' can appear sentence-initially as a subject without ambiguity:
(14)
$\begin{array}{lll}\text { mbá } \text { tsi } & \text { ni-guxn-o } & i j e ́ \\ \text { INDF REL } & \text { COMPL.AFF-read-3SG.AN } & \text { book } \\ \text { 'Someone read the book' } & \end{array}$

Both tsá and mbá tsi can occur preverbally, but, unlike 'one'-based indefinites, neither can appear sentencefinally as a subject indefinite:
(15)
*ni-guxn-o
ijé tsá/mbá tsi
COMPL.AFF-read-3SG.AN book who/INDF REL

(Intended: 'Someone read the book')

Also unlike tsá, the form mbá tsi can appear in situ:
(16) $n i '-t-a$
mbá tsi/*tsá mbá
ijé
COMPL.AFF-write-3SG.AN INDF REL
'Someone wrote a letter'
INDF.INAN letter

7. Conclusions Iliatenco Me'phaa indefinite pronouns are primarily derived from the numeral 'one,' making this system typologically unique. There is a person $v s$. non-person distinction in this paradigm, but it is counter to expectations derived from cross-linguistic evidence. In particular, in Iliatenco Me'phaa the ontological category "person" is distinguished as interrogative-based rather than 'one'-based. Syntactically, 'one'-based indefinites pattern differently than interrogative-based indefinites: numeral indefinites exhibit a subject-object asymmetry and interrogative-based subject indefinites cannot occur sentence-finally. The two "person" interrogative indefinites also differ from one another in terms of their syntactic distributions. Additionally, greater neutralization of ontological categories occurs among negative indefinites than affirmative/plain ones.

\section{References}

Carrasco Zúñiga, Abad. (2006). Los Procesos Morfofonológicos de la Lengua Méphaa [Master's Thesis].

México, D. F.: Centro de Investigaciones y Estudios Superiores en Antropología Social.

Dayley, Jon P. (1985). Tzutujil Grammar. Berkeley and Los Angeles, CA: University of California Press.

Givón, T. (1981). On the development of the numeral 'one' as an indefinite marker. Folia Linguistica Historica, 2(1), 35-54.

Haspelmath, Martin. (1993). A Grammar of Lezgian. Berlin: Mouton de Gruyter.

Haspelmath, Martin. (1997). Indefinite Pronouns. Cambridge: Cambridge University Press.

Haspelmath, Martin. (2005). Indefinite pronouns. In M. Haspelmath, M. S. Dryer, D. Gil, and B. Comrie (eds.),

The World Atlas of Language Structures, Vol. 1. Oxford: Oxford University Press, 190-193.

Insituto Nacional de Estadística y Geografía.(2005). Retrieved December 11, 2010 from

http://cuentame.inegi.gob.mx/impresion/poblacion/lindigena.asp

Lewis, M. Paul (ed). (2009). Ethnologue: Languages of the World, $16^{\text {th }}$ Ed. Dallas, TX: SIL International.

Retrieved December 11, 2010 from http://www.ethnologue.com/show language.asp?code=tcf

Marlett, Stephen A. (2011). Los números cardinales. In S. Marlett (ed.), Los Archivos Lingüísticos Me'phaa.

SIL International. Retrieved December 9, 2011, from http://www.sil.org/mexico/workpapers/WP013-

PDF/MephaaNumeros.pdf

Suárez, Jorge A. (1983). La Lengua Tlapaneca de Malinaltepec. México, D. F.: Universidad Autónoma de México.

Suárez, Jorge A. (1988). Tlapaneco de Malinaltepec. Archivo de Lenguas Indígenas de México. Mexico City: Colegio de México.

Weathers, Mark L. (1976). Tlapanec 1975. International Journal of American Linguistics, 42(4), 367-371. 